\title{
INCREASING THE STABILITY OF A LOW-EMISSION GAS TURBINE COMBUSTION CHAMBER
}

\section{ПІДВИЩЕННЯ СТІЙКОСТІ НИЗЬКОЕМІСІЙНОЇ КАМЕРИ ЗГОРЯННЯ ГАЗОТУРБІННОГО ДВИГУНА}

Serhiy I. Serbin

serhiy.serbin@nuos.edu.ua

ORCID: 0000-0002-3423-2681

Artem V. Kozlovskyi

artem.kozlovskiy@nuos.edu.ua

ORCID: 0000-0002-7604-6115

\section{C. І. Сербін,}

докт. техн. наук, професор

А. В. Козловський,

канд. техн. наук, доцент

\section{Admiral Makarov National University of Shipbuilding, Mykolaiv \\ Національний університет кораблебудування імені адмірала Макарова, м. Миколаӥв}

\begin{abstract}
Purpose. The main aim of the research is to increase the stability of gaseous fuel combustion processes in a gas turbine engine (GTE) low-emission combustors due to the plasma-chemical influence on the processes of mixture formation and gas-dynamic improvement of the flow part.

Method. The improvement of vibrating characteristics of GTE low-emission combustors with plasma-chemical stabilizer is provided by solution the main research problems in accordance with the generally accepted methodology of scientific research. The theoretical basis of the research is the scientific work of specialists in the study of hydrocarbon fuels combustion.

Results. Increasing the stability of a low-emission GTE combustion chamber operating on gaseous fuel is ensured by the influence of low-temperature plasma generators on the fuel-air mixture formation processes.

The mathematical model of unsteady processes in a GTE low-emission combustion chamber, that takes into consideration of the plasma chemical generator influence on the stability processes and allows to predict the pulsation characteristics of fuel-burning devices, is developed.

Scientific novelty. The performed numerical experiment have shown that the aerodynamic improvement of the flow part and the use of the plasma generator reduces the pressure pulsations inside flame tube by $10 \ldots 35 \%$, while in the area of primary air supply the reduction of pulsations is most pronounced.

Practical importance. Creation of a numerical experiment technique to increase the stability of gaseous fuel combustion processes in low-emission combustion chambers using modern computational hydrodynamics complexes will increase the efficiency of design and research work. Practical recommendations have been developed to improve the acoustic stability of processes in a low-emission combustion chamber with preliminary mixing of fuel with air for a $25 \mathrm{MW}$ gas turbine engine using low-current plasma-chemical generators and air-dynamic improvement of the combustion device. The results and calculating methods the characteristics of the combustion chamber with plasma chemical stabilizer are used at gas turbine enterprises in the designing new and upgrading existing models of GTE low-emission combustion chambers.
\end{abstract}

Key words: gas turbine engine; low-emission combustion chamber; pulsating combustion; unsteady combustion processes; stabilization of combustion; plasma-chemical stabilizer.

Анотація. Мета. Метою роботи є підвищення стійкості робочих процесів у низькоемісійних камерах згоряння (далі - КЗ) газотурбінних двигунів (далі - ГТД) за рахунок впливу низькотемпературної повітряної плазми на процеси сумішоутворення та газодинамічного вдосконалення проточної частини.

Методика. Удосконалення характеристик нестаціонарного робочого процесу в низькоемісійних КЗ ГТД із використанням плазмохімічного стабілізатору забезпечено розв'язанням основних дослідницьких завдань відповідно до загальноприйнятої методології наукових досліджень. Теоретичною основою роботи стали наукові праці фахівців із дослідження процесів горіння вуглеводних палив.

Результати. Стійкість процесів у низькоемісійних КЗ ГТД, що працюють на газоподібному паливі, забезпечується впливом генераторів низькотемпературної плазми на процеси утворення паливо-повітряної суміші. Розроблена математична модель нестаціонарних процесів у низькоемісійній КЗ ГТД ураховує вплив 
плазмохімічного генератора на стабільність процесів та дозволяє виявити акустичну нестійкість паливоспалювального пристрою.

Наукова новизна. У результаті виконаного числового експерименту виявлено, що аеродинамічне вдосконалювання проточної частини та використання плазмового генератора знижує пульсації тиску в жаровій трубі на $10 \ldots 35 \%$, при цьому в зоні підведення первинного повітря зменшення пульсацій виявляється найбільше.

Практична значимість. Розроблено методику числового експерименту 3 підвищення стійкості роботи низькоемісійних газотурбінних КЗ із використанням сучасних програмних комплексів обчислювальної гідродинаміки, що дозволяє підвищити ефективність проєктних робіт. Розроблено практичні рекомендації 3 підвищення акустичної стійкості КЗ ГТД потужністю 25 МВт використанням плазмохімічних генераторів та аеродинамічного вдосконалення проточної частини КЗ. Результати дослідження та методика розрахунку пульсаційних характеристик КЗ із плазмохімічними стабілізаторами використовуються на газотурбінних підприємствах під час проєктування нових та модернізації наявних зразків КЗ ГТД

Ключові слова: газотурбінний двигун; низькоемісійна камера згоряння; пульсаційне горіння; нестаціонарні процеси горіння; стабілізація горіння; плазмохімічний стабілізатор.

\section{ПОСТАНОВКА ЗАВДАННЯ}

Застосування ГТД $є$ одним із перспективних напрямів удосконалення енергетичних систем. Наразі майже не існує альтернативи цим установкам як за показниками потужності, так і за габаритними показниками. 3 огляду на це, останнє десятиліття характеризується інтенсивним розвитком газотурбобудування. Розробка високоефективних та конкурентоспроможних ГТД, які відповідають вимогам до двигунів нового покоління, $є$ актуальним народногосподарським завданням.

Перспективні ГТД повинні мати високу економічність за умов високого рівня надійності і низьких викидів шкідливих речовин. Розвиток ГТД супроводжується значним зростанням динамічних і теплових навантажень на елементи їх конструкцій, що в низці випадків супроводжується виникненням режимів вібраційного горіння. Це явище також називають нестійким горінням, термічним збудженням звуку, пульсаційним горінням. Коливання тиску можуть призвести до часткового або повного руйнування елементів конструкцій. Унаслідок інтенсифікації теплообміну в низці випадків спостерігається прогорання вузлів КЗ 3 огляду на це, забезпечення стійкості процесів у низькоемісійних КЗ $є$ актуальним завданням, що вимагає розробки науково обгрунтованих механізмів виникнення автоколивань і способів придушення пульсацій за допомогою плазмового впливу.

\section{АНАЛІЗ ОСТАННІХ ДОСЛІДЖЕНЬ І ПУБЛІКАЦІЙ}

Фундаментальними дослідженнями пульсацій газу в енергетичних установках займались: Релей, F.H. Reardon, L. Crocco, H.J. Merk, D.T. Harrje, N. Rott, A.A. Putnam, M.С. Натанзон, Н.Б. Налісний, К.I. Артамонов, Б.В. Раушенбах, В.Л. Епштейн та ін.

Розглядом різних аспектів цієї проблеми займаються в багатьох університетах, проєктних і конструкторських організаціях, як-от General Electric, Siemens, Rolls Royce, Mitsubishi, «Зоря»-«Машпроєкт», «Мотор Січ».
Незважаючи на досить велику кількість робіт у сфері наукових досліджень низькоемісійних КЗ ГТД (роботи А. Лефевра, С.І. Сербіна, Г.Б. Мостіпаненко, В.С. Костюка, А.В. Сударєва, А.М. Постнікова та ін.), а також досліджень газодинаміки низькоемісійних КЗ сучасними засобами обчислювальної гідродинаміки (А. Мелор, Н. Ріцк, Дж. Пітерс та ін.), основні аспекти вирішення питання зменшення або усунення пульсаційного горіння в низькоемісійних газотурбінних КЗ розроблено недостатньо. Актуальність теми наукового дослідження зумовлена відсутністю комплексу заходів з аналізу стійкості низькоемісійних КЗ ГТД та практичних рекомендацій із придушення режимів вібраційного горіння.

\section{ВИОКРЕМЛЕННЯ НЕ ВИРІШЕНИХ РАНІШЕ ЧАСТИН ЗАГАЛЬНОЇ ПРОБЛЕМИ}

Створення низькоемісійної КЗ ГТД тісно пов’ язане 3 можливістю математичного моделювання нестійкості горіння в КЗ на стадії проєктування. Для практичних застосувань найбільш ефективними можна вважати методи, засновані на усередненні систем рівнянь у часткових похідних, які описують закони збереження маси, енергії, імпульсу, а також перенесення хімічних компонентів. Можливості визначення раціональних геометричних і режимних параметрів паливоспалювальних пристроїв надає числовий експеримент, який можна проводити за допомогою комп'ютерних систем обчислювальної гідродинаміки.

Застосування числового експерименту на основі сучасних програмних комплексів обчислювальної гідродинаміки для виявлення режимів вібраційного горіння під час розроблення ГТД дозволить знизити витрати на проєктування та доведення ГТД, а також підвищити ефективність експлуатації двигуна.

\section{МЕТА ДОСЛІДЖЕННЯ}

Мета дослідження - підвищити стійкість робочих процесів у низькоемісійній КЗ ГТД за рахунок впливу низькотемпературної повітряної плазми на процеси сумішоутворення та газодинамічного вдосконалення проточної частини. 


\section{ЕНЕРГЕТИЧНЕ МАШИНОБУДУВАННЯ № 4ロ 2021}

\section{МЕТОДИ, ОБ'СКТ \\ ТА ПРЕДМЕТ ДОСЛІДЖЕННЯ}

Для теоретичного дослідження нестаціонарних робочих процесів у низькоемісійних КЗ із застосуванням плазмохімічного стабілізатора використано метод, заснований на числовому розв'язуванні системи диференціальних рівнянь, які описують основні закони збереження енергії та переносу хімічних компонентів, що дозволяє враховувати вплив продуктів плазмохімічних перетворень на основні процеси сумішоутворення та горіння.

Об'єктом дослідження $є$ нестаціонарні робочі процеси турбулентного горіння вуглеводного палива в низькоемісійних газотурбінних КЗ із плазмохімічним стабілізатором та газодинамічним удосконаленням проточної частини.

Предметом дослідження $\epsilon$ фізико-хімічні характеристики робочих процесів турбулентного горіння газоподібного палива, аеродинамічна структура потоків у низькоемісійній КЗ ГТД з урахуванням впливу низькотемпературної повітряної плазми на процеси утворення паливо-повітряної суміші.

\section{ОСНОВНИЙ МАТЕРІАЛ}

Проведено аналіз механізмів виникнення режимів вібраційного горіння в низькоемісійних газотурбінних КЗ та визначено вплив таких режимів на основні експлуатаційні показники ГТД. Під час пульсаційного горіння виникають такі дефекти КЗ ГТД: викривлення стінок, прогари, руйнування кріплення й ущільнень жарових труб, прогари фронтового пристрою КЗ $[1 ; 2]$.

Розглянуто можливість підвищення стійкості процесів горіння в низькоемісійних КЗ сучасних ГТД за рахунок використання плазмових генераторів та газодинамічного вдосконалення проточної частини КЗ ГТД. Показано можливість використання сучасних засобів обчислювальної гідродинаміки для виявлення процесів плазмохімічної активації горіння паливо-повітряних сумішей. Аналіз методів придушення режимів пульсаційного горіння дозволив визначити основні напрями наукового дослідження з підвищення стійкості процесів горіння в низькоемісійних КЗ ГТД.

Розроблено математичну модель нестаціонарних хімічно реагувальних потоків у низькоемісійних газотурбінних КЗ, яка дозволяє коректно прогнозувати газодинамічні та хімічні характеристики паливоспалювального пристрою КЗ і враховує плазмохімічний вплив на процеси сумішоутворення та кінетики. Модель заснована на системі диференціальних рівнянь, як-от збереження маси, збереження енергії, збереження кількості руху, переносу хімічних компонентів паливо-повітряної суміші та оксидів азоту [3-5].

Обгрунтовано використання моделі великих вихорів (LES-моделі) турбулентності під час числового експерименту 3 виявлення пульсаційних режимів у низькоемісійній КЗ ГТД із плазмохімічним стабілі- затором [6]. Запропоновано підхід до математичного моделювання впливу плазмового генератора на процеси сумішоутворення та поширення полум'я в низькоемісійній газотурбінній КЗ, в основі якого лежить залежність, що відображає вплив плазмохімічних продуктів на зменшення енергії активації результувальної реакції між паливом та окиснювачем [7].

Верифікацію математичної моделі проведено на базі отриманих експериментальних даних із дослідження пульсаційних процесів у КЗ ГТД потужністю 25 МВТ iз різними конструктивними схемами форсунок [8]. Отримані результати показали задовільну кореляцію експериментальних та теоретичних даних, а також можливість використання математичної моделі нестаціонарних робочих процесів для вдосконалення геометричних і режимних характеристик низькоемісійних КЗ ГТД із використанням стабілізаторів різних типів. Застосувати розроблену математичну модель доцільно як під час створення перспективних зразків низькоемісійних газотурбінних КЗ, що працюють на збіднених горючих сумішах, так і під час модернізації та доведення наявних КЗ ГТД із метою розробки заходів, що зменшують імовірність виникнення режимів вібраційного горіння.

Для проведення досліджень обрана КЗ двигуна потужністю 25 МВт, призначеного для приводу нагнітача природного газу. Для аналізу пульсаційних процесів побудовано об'ємну геометричну модель 1/16 частини КЗ ГТД. Паливоспалювальний пристрій (рис. 1) складається 3 трьох основних елементів: пальника 1, жарової труби 2 та вихідного дифузора 3. У жаровій трубі $є 4$ отвори для подачі вторинного повітря. У геометричній моделі додатково встановлено напрямні вихідні лопатки останнього ступеня компресора 5 та соплові лопатки турбіни високого тиску 4.

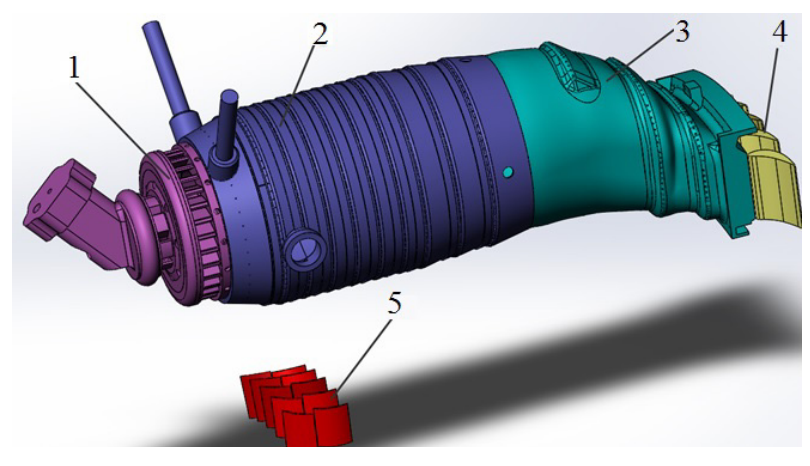

Рис. 1. Геометрична модель низькоемісійного паливоспалювального пристрою та лопаткових апаратів компресора та турбіни високого тиску

Виконані тривимірні нестаціонарні розрахунки дали змогу визначити основні особливості низькоемісійної КЗ. При розрахунках для проміжних перерізів та твердих стінок відстежувалися пульсації статичного тиску, які є джерелами акустичних коливань та можуть бути виміряні під час натурних експериментів. 


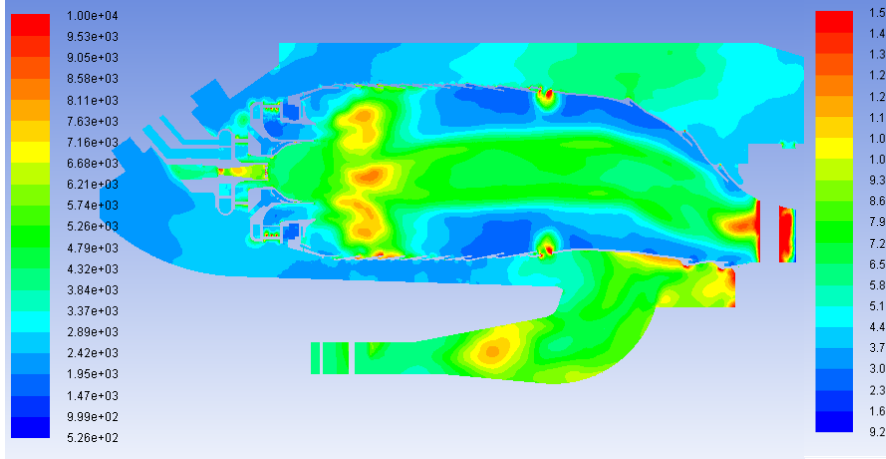

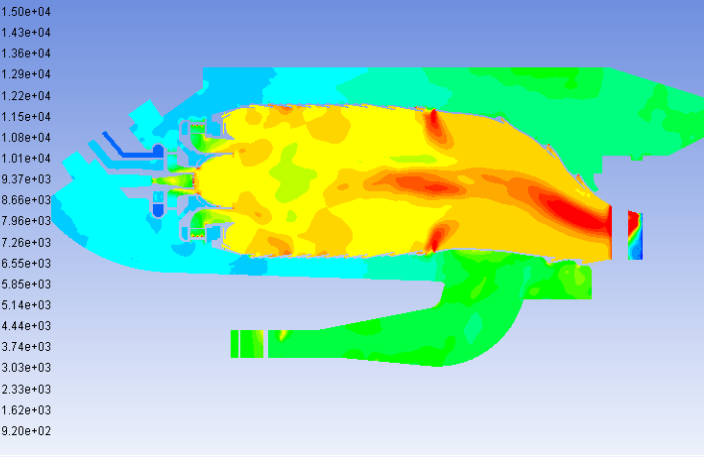

6

Рис. 2. Середньоквадратичні значення пульсацій статичного тиску в КЗ для режиму холодного продування (а) та режиму горіння (б)

Розраховано середні за часом та середньоквадратичні відхилення статичного тиску. Аналіз результатів розрахунків показав, що в передній частині жарової труби утворюється потужна зона зворотних течій, у якій мають місце максимальні температури. Саме ця зона є основним джерелом пульсацій. Зазначимо, що високий рівень пульсацій тиску спостерігається також у районі паливних струменів у сфері витікання повітря через вторинні отвори, на виході з вхідного дифузору, а також у сфері взаємодії потоку продуктів згоряння із сопловими лопатками турбіни.

Пульсації тиску на режимі горіння спостерігаються у всьому об'ємі жарової труби та мають підвищені амплітуди порівняно з режимом холодного продування (рис. 2).

Прийнято припущення, що пульсації всередині металу жарової труби не поширюються. Отже, коливання всередині жарової труби внаслідок процесу горіння мало впливають на течію повітря в міжтрубному просторі. У реальних умовах пульсації всередині жарової труби впливають на потік у міжтрубному просторі і будуть зафіксовані датчиками пульсації тиску. 3 огляду на це, розрахункові дані щодо амплітуди пульсацій потребують експериментальної верифікації.

Проведено числовий експеримент із метою прогнозування пульсаційних характеристик низькое-

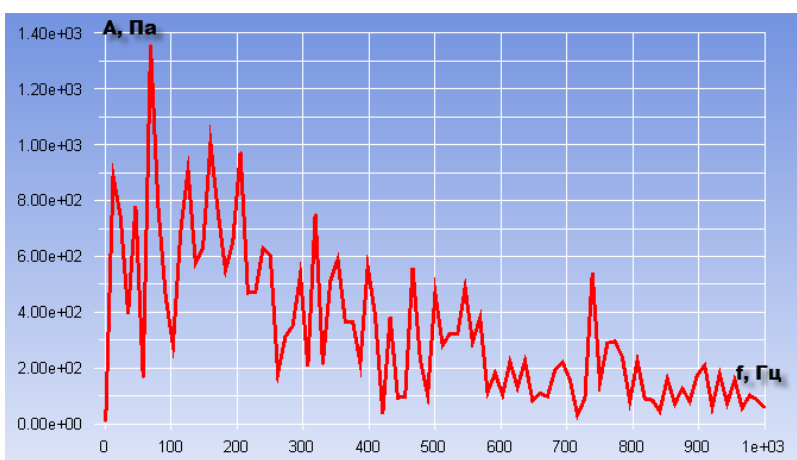

Рис. 3. Амплітуди статичного тиску в районі отвору підведення вторинного повітря місійної КЗ двигуна потужністю 25 МВт з урахуванням пульсацій тиску повітря амплітудою 3 кПа та частотою 133 Гц від компресора. Характерні частоти пульсацій тиску - 175 та 205 Гц з амплітудами $0,8 \ldots 0,4$ та $1,1 \ldots 0,5$ кПа - генеруються процесами горіння паливо-повітряної суміші. На стінках вхідного дифузора генеруються коливання тиску з високою частотою 510 Гц та амплітудою 0,45 кПа. При цьому відбувається гасіння пульсацій із частотою 510 Гц лопатками завихрювачів пальникового пристрою, а всередині жарової труби КЗ прослідковується низька частота 81 Гц з амплітудою 1,38 кПа (рис. 3).

У результаті проведення числового експерименту встановлено, що за рахунок перекриття отворів підведення вторинного повітря підвищується швидкість витікання повітря з периферійного завихрювача, що дає можливість зменшити пульсації тиску в первинній зоні газотурбінної КЗ на $10 \ldots 15$ та $30 \ldots 35 \%$ для жарової труби з двома та з одним отвором підведення вторинного повітря відповідно (рис. 4, б).

Збільшення прохідного перерізу жарової труби газотурбінної КЗ на 13,5\% призводить до зниження рівня пульсацій тиску в первинній зоні низькоемісійної К3 на $10 \ldots 20 \%$ порівняно з базовим варіантом К3 (рис. 4, в). Використання резонатора Гельмгольца в газотурбінній К3 призводить до зменшення пульсацій тиску всередині жарової труби до 20\% (рис. 4, г). При додаванні продуктів плазмохімічних реакцій кількістю $\beta=0,00087 \ldots 0,0125$ (за об'ємом) відбувається зменшення пульсацій тиску в первинній зоні К3 на 10\% (рис. 4, д), при цьому спектральна потужність статичного тиску в жаровій трубі зменшилась в $1,5 \ldots 2,0$ раза.

Крім підвищення стабільності процесів горіння паливо-повітряної суміші, використання плазмохімічних стабілізаторів дозволяє зменшити емісію токсичних компонентів. При додаванні плазмохімічних продуктів кількістю $\beta=0,00087$ (за об'ємом) розрахункові викиди оксидів азоту досягали 65,7 ppm, а підведення продуктів плазмохімічних реакцій кількістю $\beta=0,0125$ зменшило їх до 33,6 ppm, тоді як 


\section{ЕНЕРГЕТИЧНЕ МАШИНОБУДУВАННЯ № 4ロ 2021}

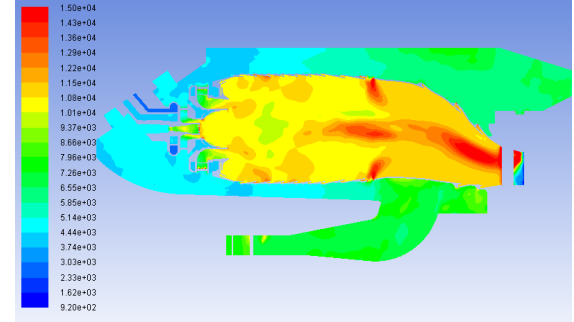

a

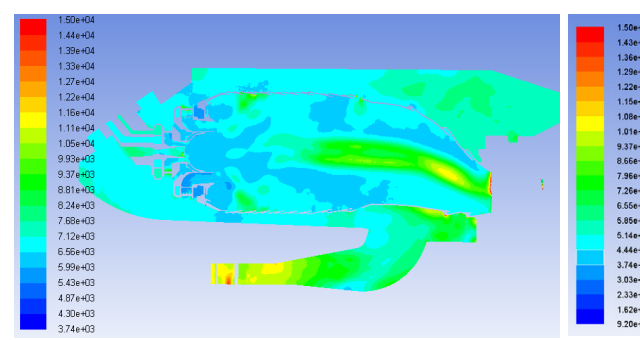

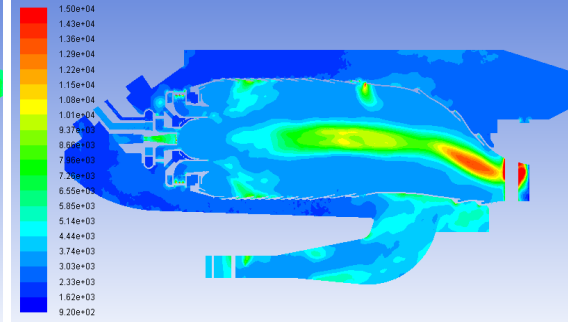

6

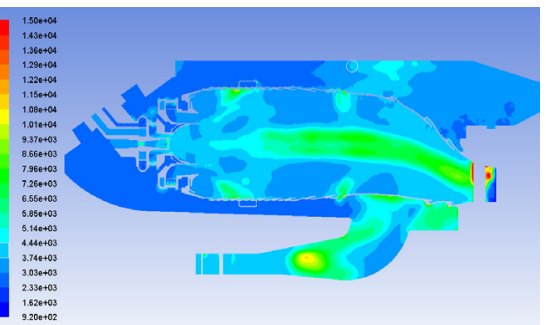

$\Gamma$

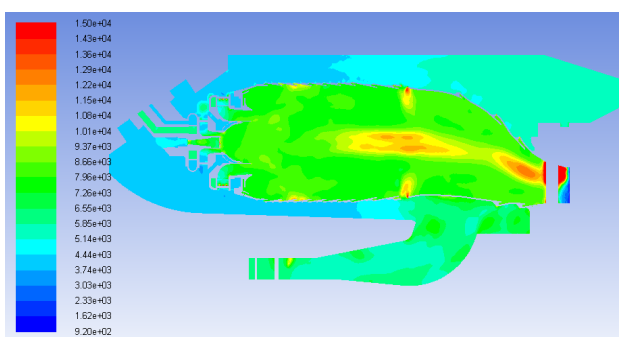

Д

Рис. 4. Рівень середньоквадратичних пульсацій статичного тиску в жаровій трубі: a - 34 отворами вторинного повітря; б - 31 отвором вторинного повітря; в - із жаровою трубою збільшеного діаметра; г - 3 резонатором; д - 3 додаванням продуктів плазмохімічних реакцій

розрахунковий рівень викидів оксидів азоту для базового варіанта газотурбінної К3 склав 82,6 ppm. Таким чином, використання плазмохімічних стабілізаторів у низькоемісійних К3 ГТД дозволить знизити рівень викидів оксиду азоту до 33,6 ppm (рис. 5, в), що не перевищує граничні норми викидів токсичних компонентів [9].

Розроблено експериментальну установку для дослідження енергетичних характеристик плазмових генераторів iз низьким енергоспоживанням, призначених для стабілізації горіння газоподібного палива в низькоемісійних К3 ГТД. Визначено діапазон стійкої роботи плазмового генератора постійного струму, призначеного для стабілізації робочих процесів у газотурбінній КЗ. Експериментальні дослідження довели ефективність слабкострумових плазмохімічних стабілізаторів [10-11].

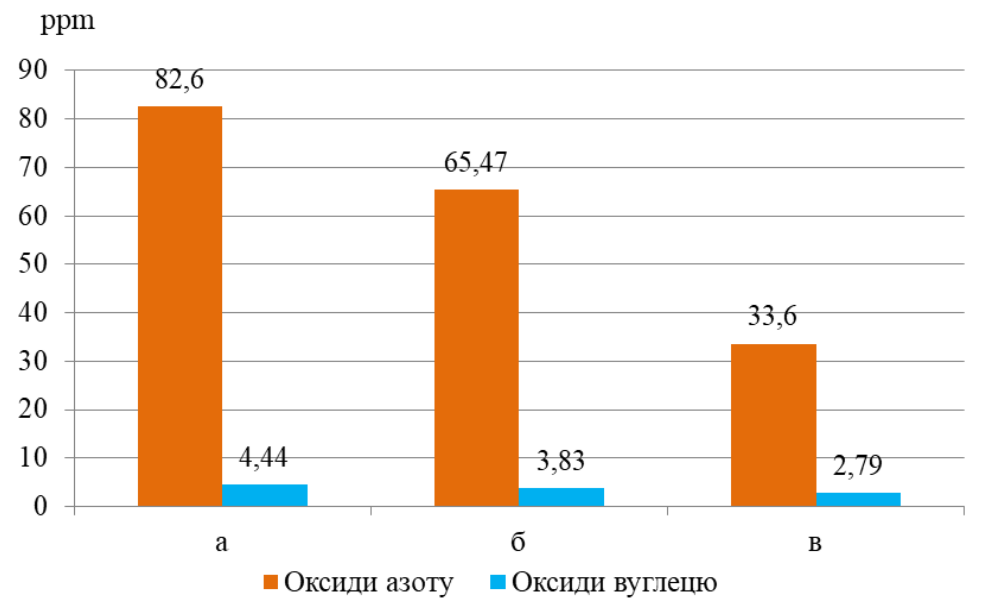

Рис. 5. Викиди оксидів азоту та вуглецю в низькоемісійній КЗ: a - базовий варіант; б - з додаванням плазмохімічних продуктів $\beta=0,00087$; в - 3 додаванням плазмохімічних продуктів $\beta=0,00125$

Упровадження рекомендацій із використання плазмохімічних стабілізаторів із низьким енергоспоживанням та вибору раціональних геометричних 
співвідношень каналів підведення повітря в практику проєктування ГТД дозволить зменшити пульсації тиску всередині КЗ та емісію токсичних речовин, знизити рівень пульсаційного горіння і, відповідно, вібрацію елементів КЗ, збільшити ресурс жарових труб КЗ та ГТД загалом.

\section{ОБГОВОРЕННЯ ОТРИМАНИХ РЕЗУЛЬТАТІВ}

Розроблено пропозиції щодо підвищення стійкості процесів горіння в низькоемісійних КЗ. На підставі отриманих теоретичних і експериментальних даних розроблено практичні рекомендації 3 підвищення стійкості режимів горіння в низькоемісійній КЗ ГТД потужністю 25 МВт. Запропоновано встановити плазмохімічний стабілізатор у центральний канал внутрішнього завихрювача пальникового пристрою 3 метою зменшення рівня пульсацій тиску в зоні основного горіння та промотувального впливу на процеси поширення полум'я.

\section{ВИСНОВКИ}

На основі огляду літературних джерел проаналізовано механізми виникнення пульсаційних режимів роботи низькоемісійних газотурбінних КЗ, а також установлено перспективні способи зменшення рівня пульсацій тиску паливо-повітряної суміші за рахунок використання слабкострумових плазмохімічних генераторів та газодинамічного вдосконалювання проточних частин низькоемісійних КЗ ГТД.

Проведено теоретичні дослідження вібраційних характеристик низькоемісійної КЗ із попереднім змішуванням паливо-повітряної суміші двигуна потужністю 25 МВт. Визначено, що рівень максимальних за амплітудою пульсацій тиску спостерігається: все- редині жарової труби в районі четвертої обичайки та в зоні рециркуляції; на стінках вхідного дифузора К3; в районі отворів витікання палива в каналах завихрювачів пальникового пристрою; в районі отворів підведення вторинного повітря; у вихідному перерізі жарової труби перед лопатками турбіни; на лопатках периферійного завихрювача пальникового пристрою.

Для всього розглянутого частотного діапазону спостерігається яскраво виражена частота 189 Гц, спричинена процесами горіння паливо-повітряної суміші, про що свідчать спектри пульсацій температури.

Для зменшення спектральної потужності статичного тиску всередині жарової труби в 1,5...2,0 раза рекомендовано підведення плазмохімічних продуктів у кількості $\beta=0,00087 \ldots 0,0125$ (за об’ємом).

Використання плазмохімічних генераторів дозволяє зменшити рівень викидів токсичних речовин. При підведенні плазмохімічних продуктів у кількості $\beta=0,00087 \ldots 0,0125$ (за об'ємом) розрахункова емісія оксидів азоту склала 65,7...33,6 ppm, тоді як рівень викидів оксидів азоту для базового варіанту газотурбінної КЗ склав 82,6 ppm.

Установлено, що в результаті підвищення швидкості витоку повітря 3 периферійного завихрювача пальникового пристрою перекриттям отворів підведення вторинного повітря можливо досягти зменшення пульсацій тиску в первинній зоні низькоемісійної газотурбінної КЗ на $10 . .35 \%$.

Розроблені практичні рекомендації щодо підвищення стійкості низькоемісійної КЗ ГТД потужністю 25 МВТ дозволять збільшити ресурс жарових труб та ГТД загалом, а також отримати економічний ефект за рахунок зниження рівня викидів токсичних компонентів.

\section{REFERENCES}

[1] Angello, L. C., \& Castaldini, C. (2004). Combustion tuning guidelines: understanding and mitigating dynamic instabilities in modern gas turbine combustors. In Turbo Expo: Power for Land, Sea, and Air (41707), 81-85.

[2] Meher-Homji, C. B., Zachary, J., \& Bromley, A. F. (2010). Gas Turbine Fuels-System Design, Combustion, And Operability. In Proceedings of the 39th turbomachinery symposium. Texas A\&M University. Turbomachinery Laboratories, 155-185.

[3] Launder B. E., \& Spalding D. B. (1972) Lectures in mathematical models of turbulence. London: Academic Press.

[4] Serbin, S. I., Matveev, I. B., \& Goncharova, N. A. (2014). Plasma-assisted reforming of natural gas for GTL-Part I. IEEE Transactions on Plasma Science, 42(12), 3896-3900.

[5] Serbin, S., Mostipanenko, A., \& Matveev, I. (2011). Investigation of the working processes in a gas turbine combustor with steam injection. In ASME/JSME Thermal Engineering Joint Conference (38921), 44042:1-6.

[6] Serbin, S. I., Kozlovskyi, A. V., \& Burunsuz, K. S. (2016). Investigations of nonstationary processes in low emissive gas turbine combustor with plasma assistance. IEEE Transactions on Plasma Science, 44(12), 2960-2964.

[7] Serbin, S., Kozlovskyi, A., \& Burunsuz, K. (2021). Influence of plasma-chemical products on process stability in a lowemission gas turbine combustion chamber. International Journal of Turbo \& Jet-Engines, 1(ahead-of-print).

[8] Serbin, S. I., Mostipanenko, A. B., Kozlovskyi, A. V., Vantsovskyi, V. G., \& Vilkul, V. V. (2014). Razrabotka metodov rascheta kharakteristik nestatsionarnogo rabochego protsessa v nizkoemissionnykh kamerakh sgoraniya GTD [Development of calculating methods characteristics of non-stationary workflow in gas turbine low-emission combustion chambers]. Vestnik Natsional'nogo tekhnicheskogo universiteta KHPI. Ser.: Energeticheskiye i teplotekhnicheskiye protsessy i oborudovaniye, (11), 90-94. (in Russian).

[9] Yevropeyskiy Soyuz: Sovet Yevropeyskogo Soyuza (2010). Direktiva 2010/75/YES Yevropeyskogo parlamenta i konsiliuma ot 24 noyabrya 2010 goda o promyshlennykh vybrosakh (integrirovannoye predotvrashcheniye i kontrol' zagryazneniya) [European Union: Council of the European Union (2010). Directive 2010/75 / EC of the European Parliament and of the Council of 24 November 2010 on industrial emissions (integrated pollution prevention and control)]. Prilozheniye V "Tekhnicheskiye polozheniya, svyazannyye so szhigayushchimi ustanovkami" [Appendix V "Technical Provisions Related to Combustion Plants"], Part 1, paragraphs 6, 59-61. (in Ukrainian). 


\section{ЕНЕРГЕТИЧНЕ МАШИНОБУДУВАННЯ № 4ロ 2021}

[10] Serbin, S. I., Kozlovskyi, A. V., \& Vilkul, S. V. (2015). Issledovaniye energeticheskikh kharakteristik plazmennogo generatora dlya stabilizatsii termo-akusticheskikh protsessov v kamerekh sgoraniya [Investigation plasma generator energy characteristics for stabilization thermo-acoustic processes in combustion chamber]. Vestnik Natsional'nogo tekhnicheskogo universiteta KHPI. Seriya: Energeticheskiye i teplotekhnicheskiye protsessy i oborudovaniye (17), 44-48. (in Russian).

[11] Kozlovskyi, A. V., \& Kirchuk, E. YU. (2015). Eksperimental'nyye issledovaniya kharakteristik plazmennogo stabilizatora dlya nizkoemissionnoy kamery sgoraniya gazoturbinnykh dvigateley [Experimental investigations of the plasma stabilizer characteristics for gas turbine low-emission combustion chamber]. Sbornik nauchnykh trudov NUOS (3), 80-84. (in Russian).

\section{СПИСОК ВИКОРИСТАНОЇ ЛІТЕРАТУРИ}

[1] Angello L.C., Castaldini C. Combustion tuning guidelines: understanding and mitigating dynamic instabilities in modern gas turbine combustors. In Turbo Expo: Power for Land, Sea, and Air (41707), 2004. 81-85.

[2] Meher-Homji C.B., Zachary J., Bromley A.F. Gas Turbine Fuels-System Design, Combustion, And Operability. In Proceedings of the 39th turbomachinery symposium. Texas A\&M University. Turbomachinery Laboratories, 2010. 155-185.

[3] Launder B.E., Spalding D.B. Lectures in mathematical models of turbulence. London : Academic Press. 1972.

[4] Serbin, S.I., Matveev, I.B., Goncharova N.A. Plasma-assisted reforming of natural gas for GTL-Part I. IEEE Transactions on Plasma Science, 42(12), 2014. 3896-3900.

[5] Serbin S., Mostipanenko A., Matveev I. Investigation of the working processes in a gas turbine combustor with steam injection. In ASME/JSME Thermal Engineering Joint Conference (38921), 2011. 44042:1-6.

[6] Serbin S.I., Kozlovskyi A.V., Burunsuz K.S. Investigations of nonstationary processes in low emissive gas turbine combustor with plasma assistance. IEEE Transactions on Plasma Science, 44(12), 2016. 2960-2964.

[7] Serbin S., Kozlovskyi A., Burunsuz K. Influence of plasma-chemical products on process stability in a lowemission gas turbine combustion chamber. International Journal of Turbo \& Jet-Engines, 1(ahead-of-print). 2021.

[8] Сербин С.И., Мостипаненко А.Б., Козловский А.В., Ванцовский В.Г., Вилкул В.В. Разработка методов расчета характеристик нестационарного рабочего процесса в низкоэмиссионных камерах сгорания ГТД. Вісник Національного технічного університету ХПІ. Сер.: Енергетичні та теплотехнічні прочеси й устаткування, (11), 2014. С. 90-94.

[9] Європейський Союз: Рада Європейського Союзу, Директива 2010/75/ЄС Європейського парламенту та ради від 24 листопада 2010 року про промислові викиди (інтегроване запобігання та контроль забруднення) / Додаток V Технічні положення, пов'язані зі спалювальними установками, Ч. 1, П. 6, С. 59-61.

[10] Сербин С.И., Козловский А.В., Вилкул С.В. (). Исследование энергетических характеристик плазменного генератора для стабилизации термо-акустических процессов в камерах сгорания. Вісник Наиіонального технічного університету «ХПІ». Серія: Енергетичні та теплотехнічні процеси й устаткування, 2015. (17), С. 44-48.

[11] Козловский А.В., Кирчук Е.Ю. Экспериментальные исследования характеристик плазменного стабилизатора для низкоэмиссионной камеры сгорания газотурбинных двигателей. Збірник наукових праиь Начіонального університету кораблебудування, 201.5 (3), С. 80-84.

(C) Сербін С. І., Козловський А. В. Дата надходження статті до редакції: 02.12.2021 Дата затвердження статті до друку: 15.12.2021 